\title{
MCM2 and MCM5 as Prognostic Markers in Colon Cancer: A Worthwhile Approach
}

\section{Maximilian Burger}

Published online: 8 September 2008

(C) Springer Science+Business Media, LLC 2008

\section{Erratum to: Dig Dis Sci}

\section{DOI 10.1007/s10620-008-0416-6}

The article was published with an incorrect listing for reference 1 . The correct listing for reference 1 is:

Giaginis C, Georgiadou M, Dimakopoulou K, Tsourouflis G, Gatzidou E, Kouraklis G, Theocharis S (2008)
Clinical significance of MCM-2 and MCM-5 expression in colon cancer: association with clinicopathological parameters and tumor proliferative capacity. Dig Dis Sci. doi: 10.1007/s10620-008-0305-z

The online version of the original article can be found under doi:10.1007/s10620-008-0416-6.

M. Burger $(\bowtie)$

Department of Urology, University of Regensburg,

Regensburg, Germany

e-mail: maximilian.burger@klinik.uni-regensburg.de 